\title{
Identification of drug-related problems of elderly patients discharged from hospital
}

\author{
This article was published in the following Dove Press journal: \\ Patient Preference and Adherence \\ 4 February 2014 \\ Number of times this article has been viewed
}

\author{
Abeer Ahmad' \\ M Ruth Mast' \\ Giel Nijpels ${ }^{2}$ \\ Petra JM Elders ${ }^{2}$ \\ Jacqueline M Dekker ${ }^{3}$ \\ Jacqueline G Hugtenburg' \\ 'Department of Clinical Pharmacology \\ and Pharmacy, ${ }^{2}$ Department of \\ General Practice, ${ }^{3}$ Departments \\ of Epidemiology and Biostatistics, \\ EMGO Institute for Health and Care \\ Research, VU University Medical \\ Center, Amsterdam, the Netherlands
}

Correspondence: Jacqueline G Hugtenburg Department of Clinical Pharmacology and Pharmacy, EMGO Institute for Health and Care Research, VU University Medical Center, Amsterdam, the Netherlands $\mathrm{Tel}+3$ I 204443524

Fax +3। 204443525

Email jg.hugtenburg@vumc.nl
Background: Drug-related problems (DRP) following hospital discharge are common among elderly patients using multiple drugs for the treatment of chronic diseases. The aim of this study was to investigate the occurrence of DRP in these patients using a specific tool for the identification of DRP by community pharmacists.

Methods: An observational study involving 340 patients aged over 60 years using at least five prescription drugs and discharged from hospital. The occurrence of DRP was assessed by means of an identification tool specifically developed for use by community pharmacists, including a semistructured patient interview and a checklist of common DRP.

Results: In total, 992 potential DRP were observed in the 340 patients (mean $2.9 \pm 1.7$ ). No drug prescribed but clear indication, an unnecessarily long duration of treatment, dose too low, and incorrect drug selection were the DRP most commonly observed. Ten percent of DRP occurring in 71 patients were drug-drug interactions. The number of DRP was related to the number of drugs prescribed. Frequently occurring DRP found using the patient interview were fear of side effects and no or insufficient knowledge of drug use. Medication of patients discharged from the pulmonary department and of those with type 2 diabetes was particularly associated with occurrence of DRP.

Conclusion: Following hospital discharge, DRP occur frequently among elderly patients using five or more drugs for the treatment of chronic disease. The number of DRP increased with the number of drugs used. An important task for community pharmacists is to identify, resolve, and prevent the occurrence of DRP among this patient group. Since DRP are associated with an increased risk of hospital readmissions, morbidity, and mortality, it is very important to develop intervention strategies to resolve and prevent DRP.

Keywords: drug-related problems, elderly, discharge from hospital, community pharmacy

\section{Introduction}

The global population is aging. In 1950, there were 205 million people aged 60 years and older and this number is expected to increase to nearly 2 billion in $2050 .{ }^{1}$ Particularly for the treatment of chronic diseases, elderly patients were found to use about three times more drugs than younger patients. ${ }^{2}$ They are therefore at a higher risk of experiencing drug-related problems (DRP). ${ }^{3-6}$ DRP described in the literature include contraindications, drug-drug interactions, adverse drug reactions, prescription errors, and noncompliance with drug use. ${ }^{2,7-10}$ With respect to older patients with comorbidities and using multiple drugs, DRP are associated with an increased risk of hospital readmissions, morbidity, and mortality. ${ }^{11,12}$ Discharge of patients from the hospital setting to home care is another important risk factor for DRP. ${ }^{13}$ 
Lack of continuity of care and discontinuity of medication following inadequate transfer of information between hospital and primary care, especially in the event of changes in the drug regimen, were found to be major underlying causes. $^{14-16}$

Several explicit criteria have been developed to identify DRP among older patients with chronic diseases. ${ }^{17-20}$ Explicit criteria, occasionally combined with other measures, are also used as tools to conduct medication reviews. ${ }^{21}$ After their introduction in the US in 1991, the Beers' criteria listing drugs inappropriate for elderly patients and adapted sets in various countries, have been revised and refined. ${ }^{18,19,22}$ STOPP (Screening Tool of Older Person's Prescriptions)/START (Screening Tool to Alert doctors to Right Treatment) criteria have addressed several shortcomings of the Beers' criteria, including detection of undertreatment, inclusion of drugs not available outside the US, and lack of physiologic categorization. ${ }^{18,19,23}$ However, these tools appear less useful in identifying DRP among older patients, since medical status and clinical parameters are not taken into account. Moreover, these evaluations do not consider patients' experience of their treatment. ${ }^{24-27}$ With the aim to facilitate the identification of DRP among these patients, we have developed a tool consisting of a checklist of commonly occurring DRP and a semistructured patient interview to support the performance of a medication review (Mast et al, unpublished data, 2013).

Few studies have assessed the frequency and specific nature of DRP among older patients with multiple drug use discharged from hospital. Probably due to differences in setting, patient characteristics, and measures addressing possible DRP, the results of these studies are also inconsistent. ${ }^{28,29}$ In order to develop effective interventions to identify and address these DRP, it is very important to get more insight into the specific nature of DRP in this specific patient group and determinants of their occurrence. The aim of the present study was to investigate the nature and frequency of prescriber-related and patient-experienced DRP among older patients using multiple chronic drugs on discharge from hospital. The effect of determinants on the occurrence of these DRP was also studied.

\section{Materials and methods Setting and participants}

This observational study was conducted with patients discharged from academic and nonacademic hospitals in the Amsterdam area. In total, eight hospitals were involved, of which two were academic and six were nonacademic.
Twenty-three community pharmacists serving patients in the region participated. The present observational study, analyzing baseline data, was part of a randomized controlled study of the effect of medication review by community pharmacists on the occurrence of DRP among elderly patients discharged from hospital. The design of this trial, as approved by the ethical committee of the VU University Medical Center in 2007, has been described previously. ${ }^{30}$

Patients aged 60 years or older, using five or more chronic drugs, and discharged from hospital in the period from 2008 to 2010, were asked to participate by their community pharmacist. Patients using five of more chronic drugs were selected because polypharmacy is generally defined as five or more chronic drugs. Each community pharmacy aimed to include 15-20 patients. Patients discharged from psychiatric or oncology departments were excluded, because less common DRP were expected in these patient groups. Those discharged to a nursing home and those not able to understand the Dutch language were also excluded. Patients willing to participate were sent an information leaflet after which pharmacy technicians invited them to visit the pharmacy within 2 weeks. If necessary or requested, patients were also visited at home. Patients were asked for written informed consent.

\section{Assessment of drug-related problems}

DRP are events or circumstances involving drug therapy that actually or potentially interfere with desired health outcomes (definition by Pharmaceutical Care Network Europe [PCNE] 2006). ${ }^{31}$ We assessed DRP by means of a structured medication review. To support the structured medication review, we developed a tool including a checklist of commonly occurring DRP and a semistructured patient interview. The tool was developed because existing tools, including the Beers' list, STOPP/START criteria, and Australian list do not include the patients' perspective and were not specifically developed for the detection of common DRP as part of a structured medication review. ${ }^{22,24,29,32}$ Development and validation of the tool have been described elsewhere (Mast et al, unpublished data, 2013). A summary of the possible DRP that could be identified with the checklist is shown in Supplement 1.

Medication records kept in the electronic pharmacy administration and information systems of the participating pharmacies (PAIS) listing all drugs prescribed and dispensed during the 6 months preceding the date of discharge were printed. In addition, general practitioners were contacted for information about the chronic diseases of each patient. 
PAIS were also used for identification of possible drug-drug interactions. ${ }^{33}$ The semistructured patient interview was used to identify DRP experienced by patients, like ineffectiveness of treatment, side effects, and fear of side effects.

Using the checklist medication records, hospital discharge prescriptions, interview data, and other relevant information (eg, PAIS signals) were reviewed by two experienced clinical pharmacologists. DRP were categorized according to a number of key items using the PCNE classification scheme (Table 1). ${ }^{30}$ Each clinical pharmacologist independently conducted a structured medication review for each patient, after which the results were compared and differences reconciled.

\section{Statistical analysis}

The baseline characteristics of all patients were analyzed. The occurrence of DRP (based on the final result of the structured medication review) was calculated by dividing the total number of (potential) DRP by the number of patients. Linear regression analysis was performed using DRP as a dependent variable and the following independent variables: age, sex, number of medication used by a patient, discharge from different hospital departments, and chronic disease. The effect of number of drugs taken by the patient on the number of DRP was adjusted for age and sex. The number of drugs taken by the patient had a significant effect on the occurrence of DRP. Therefore, discharge and chronic diseases were adjusted for age, sex, and number of drugs. The nonstandardized $\mathrm{B}$ and $95 \%$ confidence intervals are presented. The nonstandardized B regression coefficient indicates the change in number of DRP with a one unit

Table I Categories of drug-related problems

\begin{tabular}{ll}
\hline Use checked with & Drug-related problems: key items \\
\hline Review & Incorrect drug choice \\
& No drugs prescribed but clear indication \\
& Dose too low \\
& No clear indication of drug use \\
Contraindication & Unnecessarily long duration of treatment \\
& Double medication \\
& Dose too high \\
& No drugs administered \\
& Drug-drug interaction \\
Pharmacy administration & \\
and information system & Ineffectiveness \\
Interview with patient & Side effects of drug use \\
& No knowledge of drugs used \\
& Not satisfied with medication \\
& Fear of side effects \\
\hline
\end{tabular}

change in the independent variables (age, sex, number of drugs taken, hospital departments, and chronic disease). The different departments were analyzed using dummy variables and cardiology as a reference group because most patients were discharged from this department during the study. The statistical analysis was performed using Statistical Package for the Social Sciences version 15 software (SPSS Inc, Chicago, IL, USA).

\section{Results}

Of 489 patients discharged from the participating hospitals, $340(69.5 \%)$ were willing to participate in the study. Of the 149 nonresponders, 121 felt too sick and 32 considered participation to be too time-consuming. Age and the percentage of females among responders and nonresponders were similar. Nonresponders were slightly older than responders, but the difference was not significant. The mean age and percentage of females among responders and nonresponders was $75.4 \pm 8.7$ and $78.1 \pm 9.0$ years and $54 \%$ and $48 \%$, respectively. The majority of patients were discharged from cardiology, followed by internal medicine, pulmonary, surgery, and the coronary care unit department (Table 2). Most patients suffered from a chronic disease, such as heart failure, hypertension, angina pectoris, diabetes type 2 , or atrial fibrillation.

\section{Drug-related problems}

Table 3 lists the DRP identified by the structured medication review process. A total of 992 (potential) DRP were observed in the data of the 340 patients who participated (mean $2.9 \pm 1.7$ ). For nearly all patients $(95.9 \%$ ), at least one existing or potential DRP was detected. Two or more DRP were identified in $78 \%$ of patients. The number of DRP was significantly associated with the number of drugs per patient $(P<0.001)$. The most common DRP identified using the checklist included no drugs prescribed but clear indication, unnecessarily long duration of treatment, too low dose of drug, and incorrect drug selection. Ten percent of DRP associated with medication in 71 patients were drugdrug interactions.

Frequently occurring DRP identified by patient interview were fear of side effects and no knowledge of drug use. Table 4 shows the influence of different factors on the number of DRP corrected for age and sex. For patients discharged from the department of pulmonary diseases, significantly more DRP were found, as well as for patients suffering from type 2 diabetes. Adjustment for age, sex, and number of drugs taken did not alter this ranking. 
Table 2 Patient characteristics $(n=340)$

\begin{tabular}{|c|c|c|}
\hline Determinants & $\mathrm{n}, \%$ & $\begin{array}{l}\text { Median (range } \\
\text { of DRP) }\end{array}$ \\
\hline Sex, female & $183(53.8)$ & \\
\hline \multicolumn{3}{|l|}{ (median and range) } \\
\hline$<76$ & & $3(0-8)$ \\
\hline$>76$ & & $3(0-9)$ \\
\hline $\begin{array}{l}\text { prescribed per patient } \\
\text { (median and range) }\end{array}$ & & $8.0(5-24)$ \\
\hline$<8$ & & $3(0-7)$ \\
\hline$>8$ & & $3(0-9)$ \\
\hline \multicolumn{3}{|l|}{ Hospital departments } \\
\hline Cardiology & $155(45.6)$ & $3(0-7)$ \\
\hline Internal medicine & $72(21.2)$ & $3(0-7)$ \\
\hline Pulmonary & $31(9.1)$ & $4(0-9)$ \\
\hline Surgery & $19(5.6)$ & $3(0-7)$ \\
\hline Coronary care unit & $15(5.3)$ & $2.5(0-8)$ \\
\hline Others & $45(13.2)$ & 2.9 \\
\hline \multicolumn{3}{|l|}{ Chronic diseases* } \\
\hline Heart failure & $138(40.6)$ & $3(0-7)$ \\
\hline Hypertension & $130(38.2)$ & $3(0-7)$ \\
\hline Angina pectoris & $90(26.5)$ & $3(0-7)$ \\
\hline Type 2 diabetes & $73(21.5)$ & $3(0-8)$ \\
\hline Atrial fibrillation & $67(19.7)$ & $3(0-8)$ \\
\hline Others & $528(I 55.5)$ & 3.1 \\
\hline
\end{tabular}

Note: *Patients could have more than one chronic disease.

Abbreviation: DRP, drug-related problems.

Table 3 Nature and frequency of drug-related problems among elderly discharged from hospital

\begin{tabular}{|c|c|c|c|}
\hline & Frequency & $\%$ & $\begin{array}{l}\text { Patients* } \\
\mathrm{n}=\mathbf{3 4 0}\end{array}$ \\
\hline \multicolumn{4}{|l|}{ Pharmacy computer system } \\
\hline Interactions & 97 & 9.8 & 71 \\
\hline \multicolumn{4}{|l|}{ Review } \\
\hline Incorrect drug choice & 81 & 8.2 & 74 \\
\hline $\begin{array}{l}\text { No drugs prescribed but clear } \\
\text { indication }\end{array}$ & 160 & 16.1 & 139 \\
\hline Dose too low & 48 & 4.8 & 46 \\
\hline No clear indication for drug use & 12 & 1.3 & II \\
\hline Contraindication & 3 & 0.3 & 3 \\
\hline $\begin{array}{l}\text { Unnecessarily long duration } \\
\text { of treatment }\end{array}$ & 106 & 10.7 & 89 \\
\hline Double medication & 14 & 1.4 & 14 \\
\hline Dose too high & 3 & 0.3 & 3 \\
\hline No drugs administered & 1 & 0.1 & 1 \\
\hline \multicolumn{4}{|l|}{ Interview } \\
\hline Ineffectiveness & 19 & 1.9 & 19 \\
\hline Side effects of drug use & 174 & 17.5 & 174 \\
\hline No knowledge of drugs used & 145 & 14.6 & 145 \\
\hline Not satisfied with medication & 68 & 6.9 & 68 \\
\hline Fear of side effects & 61 & 6.1 & 61 \\
\hline Total DRP & 992 & 100 & \\
\hline
\end{tabular}

Note: *Each patient could have more than one DRP and is counted more than once. Abbreviation: DRP, drug-related problems.
Table 4 Effects of number of drugs used, departments, and chronic disease on number of drug-related problems

\begin{tabular}{lll}
\hline Variables & B & $\mathbf{9 5 \%} \mathbf{C l}$ \\
\hline Age & -0.13 & \\
Gender & 0.167 & \\
Number of drugs** & 0.104 & \\
Department & & \\
$\quad$ Internal versus cardiology & 0.167 & -0.290 to 0.623 \\
$\quad$ Pulmonary versus cardiology & 0.848 & 0.215 to 1.48 I* \\
$\quad$ CCU versus cardiology & 0.139 & -0.666 to 0.944 \\
$\quad$ Surgery versus cardiology & 0.306 & -0.472 to 1.058 \\
$\quad$ Others versus cardiology & 0.096 & -0.447 to 0.640 \\
Chronic disease*** & & \\
$\quad$ Heart failure & -0.46 & -0.412 to 0.319 \\
$\quad$ Hypertension & -0.185 & -0.550 to 0.179 \\
$\quad$ Angina pectoris & 0.175 & -0.226 to 0.577 \\
$\quad$ Type 2 diabetes & 0.725 & 0.299 to $1.150^{*}$ \\
$\quad$ Atrial fibrillation & 0.237 & -0.21 t to 0.684 \\
\hline Notes: $<0.05 ;$ &
\end{tabular}

Notes: $* P<0.05$; $* *$ corrected for age and sex; $* * *$ corrected for age, sex, and number of drugs; $F$ test for equality of five departments yields: $F 5.332=1.41$; $P=0.221$.

Abbreviations: $\mathrm{Cl}$, confidence interval; $\mathrm{CCU}$, coronary care unit; $\mathrm{B}$, Beta.

\section{Discussion}

This study shows that DRP occur frequently among elderly patients discharged from hospital and using several drugs to treat chronic diseases. The number of DRP was also significantly associated with the number of drugs prescribed. Moreover, patients with type 2 diabetes had significantly more DRP than patients with other diseases. Patients discharged from the department of pulmonary diseases also had more DRP than those discharged from other departments. Prescriberrelated DRP most commonly detected by conducting the structured medication review were no drug prescribed but clear indication, unnecessarily long duration of treatment, incorrect drug choice, dose of drug used being too low, and drug-drug interactions. Side effects and lack of knowledge about the drugs were the most common DRP identified by patient interview.

Several studies have also found a high prevalence of DRP among patients discharged from hospital. ${ }^{8,13,29,34}$ In this respect, changes in the drug regimen during hospital admission and the high number of drugs used are contributing factors.

Polypharmacy is a major risk factor in experiencing DRP. As expected, the number of DRP per patient increased with an increase in the number of drugs used. ${ }^{35,36}$ In line with the results of previous studies, ${ }^{9,29,37}$ patients with type 2 diabetes appeared to have more DRP than patients with other chronic diseases. International guidelines recommend that patients with type 2 diabetes 
should be treated with a cholesterol-lowering drug. ${ }^{38}$ The frequent absence of these drugs in the medication of these patients strongly contributed to the prominent presence of the DRP "no drug but clear indication" among patients in this specific group.

We also found that patients discharged from the pulmonary department had more DRP. Stuurman-Bieze et al have already observed that patients using pulmonary drugs have a high number of DRP, and suggested that this was due to a lack of knowledge about their medication and its use, including insufficient skills to use an inhaler properly. ${ }^{39}$

In line with the literature, the proportion of drug-drug interactions in our study was approximately 0.3 per patient. The number of drug-drug interactions reported varies from 0.05 per patient to 1.4 in the studies of Paulino et al and Vinks et al, respectively, ${ }^{2,8}$ which may be explained by differences in the study set-up and population. Paulino et al did not use the medication history of patients, which limited their capacity to detect interactions. ${ }^{2}$

In the present study, about $50 \%$ of the DRP were prescriber-related. In older patients discharged from a cardiology department, more than half of DRP were prescriber-related. ${ }^{2,40}$ More than half of the patients were reported to have experienced at least one side effect. This percentage is considerably higher than that found in other studies of elderly patients discharged from hospital. ${ }^{8,34,41,42}$ The difference can be explained by the number of drugs used by each patient. The present study included only patients using five or more drugs, whereas in other studies any number of drugs could be used. The high prevalence of side effects also corroborates the results of Creswell et al, who showed that the number of drugs used by older patients was a risk factor for occurrence of side effects. ${ }^{43}$

Not knowing the purpose and use of at least one of their medicines and fear of side effects were also DRP frequently reported by patients. The former DRP was also reported in other studies, ${ }^{8,40}$ and the latter DRP was reported by no less than $20 \%$ of patients. A similar percentage was found in the only study in which this patient-related DRP was also observed ${ }^{35}$ Both these DRP are important factors contributing to nonadherence with drug treatment. These issues therefore should be specifically addressed when patients are counseled on their medication. ${ }^{44,45}$

The strength of the present study was the large number of patients who participated and the high response rate. However, a substantial number of patients did not participate because of the severity of their illness or the idea that participating would be time-consuming. This may have introduced a selection bias because occurrence of DRP is likely to be high in this group of patients, and the number of DRP identified might have been underestimated.

In addition to the study aim, the present study also further validated the method used to identify DRP. The tool used to evaluate DRP was initially developed on the basis of an extensive literature search and a face validity procedure with experts (Mast et al, unpublished data, 2013). Research assistants interviewed patients. Although they may have had varying capacity to identify DRP, a structured interview was used to minimize these differences.

Certain DRP identified using the checklist as part of the structured medication review, might not be actual DRP because of a decision by the prescriber to deviate from existing standards, taking into account the individual characteristics of the patients. We therefore did not classify DRP as actual problems, but as potential problems.

Discharge of elderly patients from hospital using five or more drugs for treatment of chronic disease is associated with DRP. As confirmed by the results of the present study, the number of DRP increases with the number of drugs prescribed. Particularly in the patient group included in the present study, occurrence of DRP may result in increased risk of hospital readmission, morbidity, mortality, and health care costs. An important task for community pharmacists is therefore to identify, resolve, and prevent the occurrence of DRP in this group of patients which, in the coming years, is expected to grow considerably in size. Using comprehensive tools to identify DRP, it is very important to develop intervention strategies to achieve this goal.

\section{Acknowledgments}

We thank the participating community pharmacists and pharmacy technicians for their time and assistance with data collection. We thank The Netherlands Organisation for Health Research and Development and Pfizer BV for their financial support.

\section{Disclosure}

The authors report no conflicts of interest.

\section{References}

1. The Population Division of the Department of Economic and Social Affairs of the United Nations. World Population Ageing 1950-2050. Available from: http://www.un.org/esa/population/publications/ worldageing19502050/. Accessed August 23, 2013.

2. Vinks TH, de Koning FH, de Lange TM, Egberts TC. Identification of potential drug-related problems in the elderly: the role of the community pharmacist. Pharm World Sci. 2006;28:33-38. 
3. Drenth-van Maanen AC, van Marum RJ, Knol W, van der Linden CM, Jansen PA. Prescribing optimization method for improving prescribing in elderly patients receiving polypharmacy: results of application to case histories by general practitioners. Drugs Aging. 2009;26: $687-701$.

4. Frazier SC. Health outcomes and polypharmacy in elderly individuals: an integrated literature review. J Gerontol Nurs. 2005;31:4-11.

5. Leendertse AJ, Egberts AC, Stoker LJ, van den Bemt PM. Frequency of and risk factors for preventable medication-related hospital admissions in The Netherlands. Arch Intern Med. 2008;168:1890-1896.

6. Runciman WB, Roughead EE, Semple SJ, Adams RJ. Adverse drug events and medication errors in Australia. Int $J$ Qual Health Care. 2003;15 Suppl 1:i49-i59.

7. Passarelli MC, Jacob-Filho W, Figueras A. Adverse drug reactions in an elderly hospitalised population: inappropriate prescription is a leading cause. Drugs Aging. 2005;22:767-777.

8. Paulino EI, Bouvy ML, Gastelurrutia MA, Guerreiro M, Buurma H. DRPs identified by European community pharmacists in patients discharged from hospital. Pharm World Sci. 2004;26:353-360.

9. Stafford AC, Tenni PC, Peterson GM, et al. Drug-related problems identified in medication reviews by Australian pharmacists. Pharm World Sci. 2009;31:216-223.

10. Strand LM, Morley PC, Cipolle RJ, Ramsey R, Lamsam GD. Drug-related problems: their structure and function. DICP. 1990;24:1093-1097.

11. Roughead EE, Semple SJ. Medication safety in acute care in Australia: where are we now? Part 1: a review of the extent and causes of medication problems 2002-2008. Aust New Zealand Health Policy. 2009;6:18

12. Stewart S, Pearson S, Luke CG, Horowitz JD. Effects of home-based intervention on unplanned readmissions and out-of-hospital deaths. J Am Geriatr Soc. 1998;46:174-180.

13. Nazareth I, Burton A, Shulman S, Smith P, Haines A, Timberal H. A pharmacy discharge plan for hospitalized elderly patients a randomized controlled trial. Age Ageing. 2001;30:33-40.

14. Cook RI, Render M, Woods DD. Gaps in the continuity of care and progress on patient safety. BMJ. 2000;320:791-794.

15. Kripalani S, Jackson AT, Schnipper JL, Coleman EA. Promoting effective transitions of care at hospital discharge: a review of key issues for hospitalists. J Hosp Med. 2007;2:314-323.

16. Stuffken R, Egberts TC. Discontinuities in drug use upon hospital discharge. Pharm World Sci. 2004;26:268-270.

17. Spinewine A, Schmader KE, Barber N, et al. Appropriate prescribing in elderly people: how well can it be measured and optimised? Lancet. 2007;370:173-184.

18. O'Mahony D, Gallagher PF. Inappropriate prescribing in the older population: need for new criteria. Age Ageing. 2008;37:138-141.

19. Barenholtz Levy H, Marcus E-L. Beyond the Beers criteria: a comparative overview of explicit criteria. Ann Pharmacother. 2010;44: 1968-1975.

20. Samsa GP, Hanlon JT, Schmader KE, et al. A summated score for the medication appropriateness index: development and assessment of clinimetric properties including content validity. J Clin Epidemiol. 1994;47:891-896.

21. Fiss T, Dreier A, Meinke C, van den Berg N, Ritter CA, Hoffmann W. Frequency of inappropriate drugs in primary care: analysis of a sample of immobile patients who received periodic home visits. Age Ageing. 2011;40:66-73.

22. The American Geriatrics Society Updated Beers Expert Panel. American Geriatrics Society Updated Beers Criteria 2012 for potentially inappropriate medication use in older adults. Am J Geriatr Soc 2012. 2012;60:616-631.

23. Dimitrow MS, Airaksinen MS, Kivelä SL, Lyles A, Leikola SN. Comparison of prescribing criteria to evaluate the appropriateness of drug treatment in individuals aged 65 and older: a systematic review. J Am Geriatr Soc. 2011;59:1521-1530.
24. De Smet PA, Denneboom W, Kramers C, Grol R. A composite screening tool for medication reviews of patients. General issues with specific examples. Drugs Aging. 2007;24:733-760.

25. Lowe CJ, Petty DR, Zermansky AG, Raynor DK. Development of a method for clinical medication review by a pharmacist in general practice. Pharm World Sci. 2000;22:121-126.

26. Clyne W, Blenkinsopp A, Seal R. A guide to medication review 2008. The National Presribing Centre. Available from: http://www.npc. nhs.uk/review_medicines/intro/resources/agtmr_web1.pdf. Accessed March 27, 2013.

27. Viktil KK, Blix HS, Moger TA, Reikvam A. Interview of patients by pharmacists contributes significantly to the identification of drug-related problems (DRPs). Pharmacoepidemiol Drug Saf. 2006;15:667-674.

28. Beers MH, Ouslander JG, Rollingher I, Reuben DB, Brooks J, Beck JC. Explicit criteria for determining inappropriate medication use in nursing home residents. UCLA Division of Geriatric Medicine. Arch Intern Med. 1991;151:1825-1832.

29. Garcia-Caballos M, Ramos-Diaz F, Jimenez-Moleon JJ, Bueno-Cavanillas A. Drug-related problems in older people after hospital discharge and interventions to reduce them. Age Ageing. 2010;39: 430-438.

30. Ahmad A, Hugtenburg JG, Welschen L, Dekker J, Nijpels G. Effect of medication review and cognitive behaviour treatment by community pharmacists of patients discharged from the hospital on drug related problems and compliance: design of a randomized controlled trial. BMC Public Health. 2010;10:133.

31. Zuidlaren, Pharmaceutical Care Network Europe Foundation. Pharmaceutical Care Network Europe. The PCNE Classification V 5.01. PCNE Classification for DRP. Available from: http://www.pcne.org/sig/ drp/documents/PCNE\%20classification\%20V5.01.pdf. Accessed May 29, 2006.

32. Gallagher P, Ryan C, Byrne S, Kennedy J, O’Mahony D. STOPP (Screening Tool of Older Person's Prescriptions) and START (Screening Tool to Alert doctors to Right Treatment). Consensus validation. Int J Clin Pharmacol Ther. 2008;46:72-83.

33. Martin A. [Commentaren Medicatiebewaking]. 26th ed. 2011. German.

34. Forster AJ, Clark HD, Menard A, et al. Adverse events among medical patients after discharge from hospital. CMAJ. 2004;170:345-349.

35. Krska J, Cromarty JA, Arris F, et al. Pharmacist-led medication review in patients over 65: a randomized, controlled trial in primary care. Age Ageing. 2001;30:205-211.

36. Ruths S, Straand J, Nygaard HA. Multidisciplinary medication review in nursing home residents: what are the most significant drug-related problems? The Bergen District Nursing Home (BEDNURS) study. Qual Saf Health Care. 2003;12:176-180.

37. Haugbolle LS, Sorensen EW. Drug-related problems in patients with angina pectoris, type 2 diabetes and asthma - interviewing patients at home. Pharm World Sci. 2006;28:239-247.

38. International Diabetes Federation. Global Guideline for Type 2 Diabetes. Brussels, Belgium: International Diabetes Federation; 2005. Available from: http://www.idf.org/webdata/docs/IDF\%20GGT2D.pdf. Accessed August 24, 2013.

39. Stuurman-Bieze AG, de Boer WO, Kokenberg ME, Hugtenburg JG, de Jong-van den Berg LT, Tromp TF. Complex pharmaceutical care intervention in pulmonary care: Part A. The process and pharmacists' professional satisfaction. Pharm World Sci. 2005;27:376-384.

40. Ellitt GR, Engblom E, Aslani P, Westerlund T, Chen TF. DRPs after discharge from an Australian teaching hospital. Pharm World Sci. 2010;32:622-630.

41. Gray SL, Mahoney JE, Blough DK. Medication adherence in elderly patients receiving home health services following hospital discharge. Ann Pharmacother. 2001;35:539-545.

42. Westerlund T, Almarsdottir AB, Melander A. Factors influencing the detection rate of drug-related problems in community pharmacy. Pharm World Sci. 1999;21:245-250. 
43. Cresswell KM, Fernando B, McKinstry B, Sheikh A. Adverse drug events in the elderly. Br Med Bull. 2007;83:259-274.

44. Nikolaus T, Kruse W, Bach M, Specht-Leible N, Oster P, Schlierf G. Elderly patients' problems with medication. An in-hospital and follow-up study. Eur J Clin Pharmacol. 1996;49:255-259.
45. Sturgess IK, McElnay JC, Hughes CM, Crealey G. Community pharmacy based provision of pharmaceutical care to older patients. Pharm World Sci. 2003;25:218-226. 


\section{Supplementary material}

Supplement I Summary of checklist for potential DRP in elderly patients with a chronic disease used for this study

\begin{tabular}{|c|c|c|}
\hline & DRP related to medication & \\
\hline $\begin{array}{l}\text { General medication- } \\
\text { related problems }\end{array}$ & $\begin{array}{l}\text { - Double medication } \\
\text { - Indication ended but medication was continued } \\
\text { - Unknown indication } \\
\text { - Relevant drug interactions or contraindications identified } \\
\text { by pharmacy/GP/electronic information system } \\
\text { - Medication record suggesting nonadherence }\end{array}$ & \\
\hline $\begin{array}{l}\text { Patient-related problems } \\
\text { Frailty } \\
\text { Patient perspective (interview) }\end{array}$ & $\begin{array}{l}\text { - Drugs associated with higher risk of fall incidents } \\
\text { (eg, benzodiazepines, antidepressants, antipsychotics, } \\
\text { anticholinergics, and cardiovascular medication) } \\
\text { - Use of medication with a higher risk of decline } \\
\text { of cognition (antipsychotics and anticholinergics) } \\
\text { - Treatment indication unknown to patient } \\
\text { - Absence of awareness about how to use the medication } \\
\text { - Dissatisfaction with the medication } \\
\text { - No trust in drug treatment or doubt about effectiveness } \\
\text { of the medication } \\
\text { - Adverse drug event(s) } \\
\text { - Fear for adverse drug events }\end{array}$ & \\
\hline Medical problem & DRP related to medication & DRP related to medical status \\
\hline Hypertension & $\begin{array}{l}\text { - High dosage use of NSAID } \\
\text { - Beta-blocker combined with NSAID } \\
\text { - More than three different antihypertensive drugs } \\
\text { in combination with NSAID } \\
\text { - Use of prazosin, doxazosin, or methyldopa } \\
\text { (no proven effect on cardiovascular } \\
\text { clinical outcomes) }\end{array}$ & $\begin{array}{l}\text { - Systolic blood pressure } \geq 140 \mathrm{mmHg} \\
\text { - No regular assessment of creatinine or } \\
\text { potassium blood levels in combination with } \\
\text { renal dysfunction that use diuretics, ACE } \\
\text { inhibitors, or angiotensin II antagonists } \\
\text { - Hypertension as a result of renal insufficiency } \\
\text { treated with antihypertensive medication }\end{array}$ \\
\hline Angina pectoris & $\begin{array}{l}\text { - No use of acetylsalicylic acid or other } \\
\text { antiplatelet drug } \\
\text { - Acetylsalicylic acid combined with NSAID } \\
\text { or SSRI without stomach protector } \\
\text { - Clopidogrel combined with omeprazole } \\
\text { or esomeprazole } \\
\text { - Sildenafil combined with nitrates } \\
\text { - Overuse of nitroglycerine sprays } \\
\text { - Use of short-acting nifedipine capsules }\end{array}$ & - Heart rate $\leq 50-60$ beats per minute in rest \\
\hline $\begin{array}{l}\text { Cardiovascular disease } \\
\text { (myocardial infarction, angina } \\
\text { pectoris, stroke, transient } \\
\text { ischemic attack, aorta aneurysm, } \\
\text { peripheral arterial disease) }\end{array}$ & $\begin{array}{l}\text { - Statin not prescribed or dosage too low } \\
(<40 \mathrm{mg} \text { simvastatin equivalent) } \\
\text { - No use of acetylsalicyclic acid or other } \\
\text { antiplatelet drug }\end{array}$ & - $\mathrm{LDL}>2.5 \mathrm{mmol} / \mathrm{L}$ \\
\hline Atrial fibrillation & $\begin{array}{l}\text { - Beta-blocker combined with verapamil/diltiazem } \\
\text { - Digoxin used with combination of amiodarone } \\
\text { with either verapamil or diltiazem without reduction } \\
\text { of digoxin dosage } \\
\text { - No use of coumarin although indication } \\
\text { on the basis of CHADS criteria and absence of a } \\
\text { contraindication (frequent falls, low adherence) } \\
\text { - Use of digoxin and/or verapamil and/or beta-blocker } \\
\text { in combination with sotalol, amiodarone, or a class I } \\
\text { antiarrhythmic drug }\end{array}$ & $\begin{array}{l}\text { - No monitoring of digoxin or potassium } \\
\text { blood levels } \\
\text { - Heart rate } 70-90 \text { per minute at rest or } \\
>120 \text { per minute during exercise }\end{array}$ \\
\hline Systolic heart failure & $\begin{array}{l}\text { - No use of diuretic } \\
\text { - No use of RAS inhibitor } \\
\text { - Tickling cough during use of ACE inhibitor }\end{array}$ & $\begin{array}{l}\text { - NYHA classification of heart failure is not } \\
\text { applied } \\
\text { - No renal function assessment in previous year }\end{array}$ \\
\hline
\end{tabular}

(Continued) 
Supplement I (Continued)

\begin{tabular}{|c|c|c|}
\hline Medical problem & DRP related to medication & DRP related to medical status \\
\hline & $\begin{array}{l}\text { - Use of verapamil } \\
\text { - Diltiazem or verapamil without concomitant } \\
\text { use of digoxin } \\
\text { - Chronic use of NSAID } \\
\text { - NSAID combined with high dosage loop } \\
\text { - Cruretics or thiazides } \\
\text { - } \text { and thiazide diuretic is used without concomitant } \\
\text { loop diuretic } \\
\text { - No beta-blocker } \\
\text { - No spironolactone although NYHA class II or III } \\
\text { - Coart failure and reasonable renal function } \\
\text { - Use of diuretic for static edema without diagnosis } \\
\text { - An heart failure } \\
\text { - Ankle edema due to calcium channel blocker without } \\
\text { - Reconnosis of heart failure } \\
\text { is a diagnosis of gout }\end{array}$ & \\
\hline $\begin{array}{l}\text { Anticoagulant use (use related } \\
\text { to heart disease or stroke } \\
\text { prevention) }\end{array}$ & $\begin{array}{l}\text { - INR }<2.5 \text { target is not reached } \\
\text { - Absence of gastric protective medication in } \\
\text { patients } \geq 70 \text { years of age } \\
\text { - Combination of coumarin with acetylsalicylic acid } \\
\text { or other antiplatelet drug without indication } \\
\text { - Combination of coumarin with acetylsalicylic acid } \\
\text { or other antiplatelet drug without gastric } \\
\text { protection }\end{array}$ & - INR target incorrectly set at value $<2$ or $>3$ \\
\hline $\begin{array}{l}\text { Arthritis or other rheumatic } \\
\text { disease }\end{array}$ & $\begin{array}{l}\text { - NSAID in combination with renal failure } \\
\text { - Acetylsalicylic acid in combination with NSAID } \\
\text { without gastric protection } \\
\text { - Use of NSAID without stomach protection } \\
\text { in patients } \geq 65 \text { years of age } \\
\text { - Use of NSAID whereas alternative like paracetamol } \\
\text { is possible }\end{array}$ & \\
\hline Type 2 diabetes mellitus & $\begin{array}{l}\text { - Frequent occurrence of hypoglycemic episodes } \\
\text { and use of glibenclamide } \\
\text { - Pioglitazone use in combination with loop diuretic } \\
\text { - Hypoglycemic medication combined with } \\
\text { nonselective beta-blockers (except sotalol) } \\
\text { - Statin dosage too low ( }<40 \mathrm{mg} \text { simvastatin equivalent) } \\
\text { - Concomitant use of medication that potentially } \\
\text { disturbs blood glucose levels, eg, high-dose } \\
\text { thiazides or corticosteroids } \\
\text { - Calcium channel blocker is sole antihypertensive } \\
\text { medication }\end{array}$ & $\begin{array}{l}\text { - Fasting glucose level in } \\
\text { venous plasma } 4.5-8 \mathrm{mmol} / \mathrm{L} \\
\text { - Frequent occurrence of hypoglycemic episodes } \\
\text { - } \mathrm{HbA}_{\mathrm{Ic}}>58 \mathrm{mmol} / \mathrm{L}(7.5 \%) \\
\text { - Systolic blood pressure }>/ 40 \mathrm{mmHg} \text { in absence } \\
\text { of antihypertensive drug } \\
\text { - } \mathrm{LDL}>2.5 \mathrm{mmol} / \mathrm{L} \text { or total cholesterol } \\
>4.5 \mathrm{mmol} / \mathrm{L} \text { in absence of statin } \\
\text { - (Micro) albuminuria in absence of treatment } \\
\text { with ACE inhibitor or ATI antagonist } \\
\text { - Ankle edema in combination with pioglitazone } \\
\text { - Metformin dosage not adapted because of renal } \\
\text { insufficiency } \\
\text { - Microvascular complications without } \\
\text { antihypertensive medication } \\
\text { - Renal function, HbA } \mathrm{A}_{\mathrm{I}} \text {, blood pressure, and } \\
\text { urinary microalbuminuria is not assessed } \\
\text { periodically (minimum once/year) }\end{array}$ \\
\hline Asthma/COPD & $\begin{array}{l}\text { - Daily dose of beta-sympathomimetic } \\
\text { is higher than maximum dose } \\
\text { - Daily dose of inhalation corticosteroid is } \\
\text { higher than maximum dose }\end{array}$ & $\begin{array}{l}\text { - Severity of disease not classified } \\
\text { - Fluctuating clinical status } \\
\text { - Frequent episodes of oral corticosteroids use } \\
\text { (possible sign of compliance problem) }\end{array}$ \\
\hline
\end{tabular}


Supplement I (Continued)

\begin{tabular}{|c|c|c|}
\hline Medical problem & DRP related to medication & DRP related to medical status \\
\hline & $\begin{array}{l}\text { - Severe asthma combined with beta-blocker } \\
\text { tablets or beta blocker eye drops } \\
\text { - Dosage of long-acting beta- } 2 \text { antagonist or inhalation } \\
\text { corticosteroid "if needed, if necessary or on demand" }\end{array}$ & \\
\hline Osteoporosis & $\begin{array}{l}\text { - No use of vitamin D while indicated } \\
\text { - No use of calcium while indicated } \\
\text { - Use of bisphosphonates or denosumab without } \\
\text { supplementation of calcium and vitamin D } \\
\text { - No use of bisphosphonates or previous use for } \\
\text { a period of } 5 \text { years } \\
\text { - Chronic use of high-dose ( } \geq 7.5 \text { mg prednisolone } \\
\text { equivalent) without concomitant use of a } \\
\text { - Uisphosphonate or denosumab } \\
\text { - Bisphosphonates not taken in a fasting state } \\
\text { - Simultaneous use of a bisphosphonate and a drug } \\
\text { containing Ca, Al, Mg, Fe, or Zn } \\
\text { - Severe decrease of renal function (GFR }<30 \mathrm{~mL} \\
\text { - Ver minute) and no use of vitamin D } \\
\text { - Dosage antidepressant is incorrect }\end{array}$ & \\
\hline Depression & $\begin{array}{l}\text { - Duration of treatment with SSRI }<4 \text { weeks } \\
\text { - Use of SSRI longer than } 6 \text { months after first episode } \\
\text { of depression } \\
\text { - Tricyclic antidepressant as first choice in presence } \\
\text { of cardiovascular risk factors or cardiovascular disease } \\
\text { - Tricyclic antidepressant use and a history of glaucoma, } \\
\text { orthostatic hypotension, or bladder retention } \\
\text { - Use of SSRI and history of hyponatremia }\end{array}$ & $\begin{array}{l}\text { - Continued treatment for depression without } \\
\text { indication } \\
\text { - Withdrawal symptoms due to abrupt cessation } \\
\text { - Absent monitoring of sodium blood level during } \\
\text { concomitant use of SSRI and diuretic medication }\end{array}$ \\
\hline Sleep disorder & $\begin{array}{l}\text { - Benzodiazepine prescribed other than temazepam } \\
\text { or zolpidem } \\
\text { - Chronic use of hypnotic medication } \\
\text { - Benzodiazepine dosage is too high } \\
\text { - Use of benzodiazepines with history of falls } \\
\text { - Chronic use of benzodiazepines without indication } \\
\text { for sedation or anxiolysis }\end{array}$ & \\
\hline Other psychiatric problems & $\begin{array}{l}\text { - Unnecessary or ineffective use of anticholinergic } \\
\text { medication } \\
\text { - No periodic evaluation of antipsychotic drug use } \\
\text { - Concomitant use of NSAID with lithium } \\
\text { - Use of haloperidol in patients with recent myocardial } \\
\text { infarction or heart failure, or history of ventricular } \\
\text { arrhythmias }\end{array}$ & $\begin{array}{l}\text { - Use of lithium without monitoring of lithium } \\
\text { blood level, renal function, mineral (calcium, } \\
\text { magnesium), thyroid function } \\
\text { - Use of clozapine without monitoring of white } \\
\text { blood count }\end{array}$ \\
\hline Parkinson's disease & $\begin{array}{l}\text { - Use of other antipsychotics than clozapine } \\
\text { and quetiapine }\end{array}$ & $\begin{array}{l}\text { - Consider whether symptoms could be related to } \\
\text { the use of neuroleptics, SSRI, or metoclopramide }\end{array}$ \\
\hline $\begin{array}{l}\text { Stomach pain or esophageal } \\
\text { reflux }\end{array}$ & & $\begin{array}{l}\text { - Indication for acid inhibition no longer present } \\
\text { but treatment continued }\end{array}$ \\
\hline Constipation & - Codeine prescribed for pain or coughing complaints & - Unnecessary and/or prolonged use of laxatives \\
\hline Pain & - Use of opioids without use of laxatives & \\
\hline
\end{tabular}

Abbreviations: ACE, angiotensin-converting enzyme inhibitor; ATI, angiotensin II type I receptor; CHADS, congestive heart failure/hypertension/age/diabetes mellitus/ stroke; COPD, chronic obstructive pulmonary disease; DRP, drug-related problems; INR, International Normalized Ratio; LDL, low-density lipoprotein; NYHA, New York Heart Association; SSRI, selective serotonin reuptake inhibitors; NSAID, nonsteroidal anti-inflammatory drugs; HbA $\mathrm{Ic}_{\mathrm{Ic}}$ glycosylated hemoglobin; GFR, glomerular filtration rate; GP, general practitioner; RAS, renin angiotensin system. 
Patient Preference and Adherence

Dovepress

\section{Publish your work in this journal}

Patient Preference and Adherence is an international, peer-reviewed, open access journal focusing on the growing importance of patient preference and adherence throughout the therapeutic continuum. Patient satisfaction, acceptability, quality of life, compliance, persistence and their role in developing new therapeutic modalities and compounds to optimize clinical outcomes for existing disease states are major areas of interest. This journal has been accepted for indexing on PubMed Central. The manuscript management system is completely online and includes a very quick and fair peer-review system. Visit http://www.dovepress.com/ testimonials.php to read real quotes from published authors.

Submit your manuscript here: http://www.dovepress.com/patient-preference-and-adherence-journal 